\title{
PENGARUH MOTIVASI, KOMUNIKASI DAN LINGKUNGAN KERJA TERHADAP KINERJA KARYAWAN PADA PT ANDALAN PASIFIC SAMUDRA DI SURABAYA
}

\author{
*( Yunni Rusmawati Dj \\ Fakultas Ekonomi \\ Universitas Islam Lamongan
}

\begin{abstract}
ABSTRAK
Kinerja tidak akan mencapai hasil yang maksimal bila tidak ada motivasi kerja, motivasi adalah suatu keharusan dalam upaya untuk mencapai tujuan. Motivasi adalah konsep yang kita gunakan untuk menggambarkan impuls yang timbul dalam satu individu yang mendorong dan mengarahkan perilaku. Komunikasi telah sangat penting dalam semua aspek kehidupan.Dalam penelitian ini yang merupakan variabel bebas adalah motivasi (X1), komunikasi (X2), dan Lingkungan Kerja (X3). Sedangkan variabel dependen adalah kinerja karyawan (Y). sampel dalam penelitian ini adalah seluruh karyawan PT Andalan Pacific Samudra sekitar 40 orang, semuanya diambil untuk menjadi responden. Data dikumpulkan menggunakan kuesioner dan dianalisis dengan menggunakan regresi linier berganda. Hasil penelitian menunjukkan bahwa motivasi, komunikasi, dan lingkungan kerja secara parsial berpengaruh signifikan terhadap kinerja karyawan PT Andalan Pacific Samudra. Hal ini dibuktikan dari nilai signifikan sebesar 0,000 $t$ variabel motivasi, variabel dan komunikasi variabel 0,001 0,000 lingkungan kerja. Motivasi, komunikasi, dan lingkungan kerja berpengaruh secara simultan signifikan terhadap kinerja karyawan di PT Andalan Samudera Pasifik. Hal ini dibuktikan dari nilai F signifikan 0,000 atau kurang dari 0,05
\end{abstract}

Kata kunci: motivasi, komunikasi, lingkungan kerja dan kinerja

\section{PENDAHULUAN}

Salah satu permasalahan yang dihadapi oleh perusahaan antara lain adalah rendahnya kualitas sumber daya manusia. Permasalahan dalam suatu organisasi terkait dengan sumber daya manusia adalah bagaimana menciptakan sumber daya manusia yang berkualitas agar menghasilkan kinerja yang optimal sehingga tujuan organisasi tercapai. Salah satu faktor yang mempengaruhi kepuasan kerja adalah motivasi. Tanpa adanya motivasi dari para karyawan untuk bekerja sama bagi kepentingan perusahaan maka tujuan yang telah ditetapkan tidak akan tercapai. Hal lain yang terpenting dalam organisasi adalah komunikasi. Komunikasi secara umum adalah suatu proses penyampaian dan penerimaan informasi dari seseorang ke orang lain. Keberhasilan suatu organisasi dalam mencapai tujuan juga tidak terlepas dari faktor 
lingkungan kerja. Meskipun faktor tersebut sangat penting tetapi masih banyak organisasi yang kurang memperhatikan hal tersebut. Lingkungan kerja adalah segala sesuatu yang ada disekitar para pekerja dan dapat mempengaruhi dirinya dalam menjalankan tugastugas yang dibebankan, misalnya keberhasilan dan lain-lain.

PT Andalan Pasific Samudra merupakan perusahaan yang bergerak di bidang forwader, yaitu pengiriman barang dalam negeri dan luar negeri. Dalam menjalankan usahanya tentu juga memerlukan kerja sama yang baik dan terarah dari para karyawannya sesuai dengan tujuan yang hendak dicapai. Diperlukan adanya motivasi kerja yang tepat yang dapat mempengaruhi kinerja para karyawan agar bekerja secara optimal. Karyawan PT Andalan Pasifi Samudra di Surabaya berjumlah 45 orang, yang mana masing-masing karyawan tersebut mempunyai motif maupun latar belakang kebutuhan yang berbedabeda dalam melaksanakan tugas dan pekerjannya untuk kinerja yang baik. Berdasarkan uraian di atas maka penulis tertarik untuk mengadakan penelitian tentang motivasi kerja, komunikasi, dan lingkungan kerja terhadap kinerja karyawan pada PT Andalan Pasific Samudra dengan judul :'PENGARUH MOTIVASI, KOMUNIKASI DAN LINGKUNGAN KERJA TERHADAP KINERJA KARYAWAN PADA PT ANDALAN PASIFIC SAMUDRA DI SURABAYA".

Berdasarkan uraian latar belakang masalah diatas, maka dapat dibuat rumusan masalah sebagai berikut

1. Apakah motivasi, komunikasi, dan lingkungan kerja secara parsial berpengaruh terhadap kinerja karyawan pada PT Andalan Pasific Samudra?

2. Apakah motivasi, komunikasi dan lingkungan kerja secara simultan berpengaruh terhadap karyawan pada PT Andalan Pasific Samudra?

\section{TUJUAN PENELITIAN}

Adapun tujuan penelitian ini adalah untuk mengetahui apakah motivasi, komunikasi dan lingkungan kerja secara parsial dan simultan berpengaruh terhadap kinerja karyawan pada PT Andalan Pasific Samudra di Surabaya.

Hasil dari penelitian yang penulis lakukan diharapkan dapat digunakan untuk menetapkan kebijakan, khususnya yang berkaitan dengan pemberian motivasi, komunikasi yang efektif dan penyempurnaan lingkungan kerja bagi para karyawan dan sebagai wahana informasi yang beguna khususnya dalam meningkatkan kualitas dan kinerja.

Penelitian yang dilakukan oleh Sarwono (2008) menunjukkan ada pengaruh signifikan secara parsial kemampuan, motivasi, dan lingkungan kerja terhadap kinerja guru. Secara simultan penelitian ini juga menunjukkan bahwa kemampuan, motivasi, dan lingkungan kerja berpengaruh terhadap kinerja guru dengan konstribusi sebesar $85,7 \%$. Variabel yang dominan dalam mempengaruhi kinerja guru adalah variabel motivasi kerja. Hal ini memberikan 
informasi bahwa motivasi kerja sangat diperlukan dalam setiap organisasi untuk memajukan organisasi.

Hasil penelitian yang dilakukan oleh Utami (2010) yang berjudul pengaruh kepemimpinan, motivasi, komunikasi, dan lingkungan kerja terhadap kinerja pegawai kecamatan Jumantono Kabupaten Karanganyar menunjukkan bahwa kepemimpinan berpengaruh signifikan terhadap kinerja pegawai di Kecamatan Jomantono Kabupaten Karanganyar. Hal ini dibuktikan dari hasil uji $t$ yang menghasilkan $\mathrm{p}$ value $(0,018)$ $<$ 0,05. Motivasi berpengaruh signifikan terhadap kinerja pegawai di Kecamatan Jumantono Kabupaten Karanganyar. Hal ini dibuktikan dari hasil uji $\mathrm{t}$ yang menghasilkan $\mathrm{p}$ value $(0,005)<0,05$. Motivasi berpengaruh signifikan terhadap kinerja pegawai kecamatan Jumantono Kabupaten Karanganyar. Hal ini dibuktikan dari hasil uji $t$ yang menghasilkan $\mathrm{p}$ value $(0,178)<0,05$. Variabel motivasi mempunyai pengaruh dominan terhadap kinerja pegawai di kecamatan Jumantono kabupaten Karanganyar. Hal ini dibuktikandari hasil uji $\mathrm{t}$ dimana nilai $\mathrm{t}$ hitung variabel motivasi $(3,040)$ lebih besar dibanding variabel lainnya

\section{TINJAUAN TEORI MOTIVASI}

Menurut Mangkunegara (2009:61) mendefinisikan bahwa "Motivasi kerja adalah kondisi atau energi yang menggerakkan diri karyawan yang terarah atau tertuju untuk mencapai tujuan organisasi perusahaan". Sedangkan menurut
Hasibuan (2005:95) menjelaskan bahwa "motivasi kerja adalah pemberian daya penggerak yang menciptakan kegairahan kerja seseorang, agar mereka mau bekerja sama, bekerja efektif dan terintegrasi dengan segala daya upayanya untuk mencapai kepuasan".

\section{KOMUNIKASI}

$\begin{array}{cr}\text { Sedangkan } & \text { Istijanto } \\ (2008: 67) \quad \text { berpendapat } & \text { bahwa }\end{array}$ komunikasi secara umum adalah suatu proses penyampaian dan penerimaan informasi dari seorang ke orang lain. Ilmuwan-ilmuwan perilaku yang mempelajari komunikasi menekan aliran komunikasi dan pengaruh-pengaruh komunikasi. Dalam mengukur aliran,mereka berhubungan dengan siapa yang memulai dan siapa yang menerima komunikasi, jenis-jenis informasi apakah yang disampaikan dan jaringan atau saluran apakah yang digunakan. Jaringan-jaringan bisa dibuat mulai sangat formal, misalnya jaringan-jaringan yang mengikuti saluran-saluran otoritas, sampai sangat informal, misalnya menghabiskan makan siang bersama. Komunikasi dapat mempengaruhi moril kelompok dan sikap-sikap yang dimiliki oleh individu-individu terhadap pekerjaan-pekerjaan, disiplin kerja dan teman-teman kerja mereka. Demikian pula hasil kerja individu atau kelompok dapat dipengaruhi oleh komunikasi.

\section{LINGKUNGAN KERJA PENGERTIAN LINGKUNGAN KERJA}

Salah satu faktor yang dapat mempengaruhi kinerja karyawan adalah lingkungan kerja. Meskipun 
faktor tersebut sangatlah penting dan besar pengaruhnya, tetapi masih banyak perusahaan-perusahaan yang kurang memperhatikan hal tersebut. "Yang disebut lingkungan kerja adalah segala sesuatu yang ada disekitar para pekerja dan dapat mempengaruhi dirinya dalam menjalankan tugas-tugas yang dibebankan. Misalnya kebersihan, music, dan lain-lain. (Nitisemito, 2002 : 183).

\section{KINERJA}

Menurut Mangkunegara (2001:67) "Kinerja adalah hasil kerja secara kualitas dan kuantitas yang dicapai oleh seseorang karyawan dalam melaksanakan tugasnya sesuai dengan tanggung jawab yang diberikan kepadanya". Sedangkan menurut Simamora (2001:416) "Kinerja merupakan proses dengannya organisasi mengevaluasi pelaksanaan kerja individu. Penilaian kinerja dilakukan melalui konstribusi karyawan terhadap organisasi selama periode waktu tertentu".

Berdasarkan landasan teori dan kerangka berfikir penelitian sebagaimana telah dijelaskan diatas, maka hipotesis yang dibuat adalah :

1. Motivasi, komunikasi, dan lingkungan kerja secara parsial berpengaruh terhadap kinerja karyawan pada PT Andalan Pasific Samudra di Surabaya.

2. Motivasi, komunikasi, dan lingkungan kerja secara simultan (bersama-sama) berpengaruh terhadap kinerja karyawan PT Andalan Pasific Samudra

\section{METODE PENELITIAN}

Waktu pelaksanaan penelitian dilaksanakan pada bulan Desember 2015. Penelitian ini dilakukan di PT Andalan Pasific Samudra. Alasan utama pemilihan lokasi tersebut adalah karena instansi ini merupakan perusahan yang cukup besar yang bergerak di bidang forwader yang sekarang ini peran jasa pengiriman barang dalam negeri dan luar negeri.

Sugiyono(2009:90)

menjelaskan bahwa populasi adalah wilayah generalisasi yang terdiri atas : obyek/subyek yang mempunyai kualitas dan karakteristik tertentu yang ditetapkan oleh peneliti untuk dipelajari dan kemudian ditarik kesimpulannya. Sampel adalah bagian dari jumlah dan karakteristik yang dimiliki oleh populasi tersebut. Dalam penelitian yang bertindak sebagai populasi adalah seluruh karyawan PT Andalan Pasific Samudra yang berjumlah 40 orang.

Sampel menurut Arikunto (2002:104) adalah sebagian atau wakil populasi yang diteliti. Untuk sekedar ancer-ancer, apabila subyeknya kurang dari 100 lebih baik diambil semua, sehingga penelitiannya berupa penelitian populasi. Selanjutnya jika subyeknya besar dapat diambil antara $10-15 \%$ atau $20-25 \%$ atau lebih tergantung setidak-tidaknya dari :

1. Kemampuan peneliti dilihat dari segi waktu, tenaga, dan data

2. Sempit luasnya wilayah pengamanan dari subyek karena hal ini menyangkut banyak dan sedikitnya dan

3. Besar kecilnya resiko yang ditanggung oleh peneliti, untuk penelitian yang resikonya besar tentu saja sampel lebih besar 
akan lebih baik (Arikunto, 2002 : 107)

dalam penelitian ini adalah sebanyak 40 maka tekhnik sampling yang digunakan dalam penelitian ini adalah total sampling.

1. Variabel Motivasi $\left(\mathrm{X}_{1}\right)$ Motivasi adalah keadaan dalam pribadi seseorang yang mendorong keinginan individu untuk melakukan kegiatan-kegiatan tertentu guna mencapai suatu tujuan, yang diukur dengan skala likert dengan indikator sebagai berikut :

a. Kebutuhan fisiologis, yaitu kebutuhan akan makan, minum, perlindungan fisik, bernapas, seksual. Kebutuhan ini merupakan kebutuhan tingkat terendah atau disebut pula sebagai kebutuhan yang paling dasar, diukur dari :

- Gaji yang diberikan perusahaan disesuaikan dengan taraf pendapatan minimum (UMR)

- Gaji yang diberikan perusahaan sesuai dengan beban kerja dan tanggung jawab karyawan

- Waktu untuk istirahat, makan, dan ibadah sesuai dengan kebutuhan secara umum.

b. Kebutuhan rasa aman, yaitu kebutuhan akan perlindungan dari ancaman, bahaya, pertentangan, dan lingkungan hidup, diukur dari:

- Fasilitas kerja yang lengkap

- Penetapan aturan tanpa adanya tekanan

- Iklim kerja yang kondusif terhadap pengembangan daya kreasi dan inovasi

- Program tunjangan kesehatan

c. Kebutuhan akan rasa memiliki, yaitu kebutuhan untuk diterima oleh kelompok, berafiliasi, berinteraksi, dan kebutuhan untuk mencintai dan dicintai, diukur dari :

- Hubungan yang baik antara atasan dan bawahan di lingkungan kerja

- Hubungan antar karyawan di perusahaan.

- Adanya acara-acara peringatan

d. Kebutuhan akan harga diri, yaitu kebutuhan untuk dihormati, dan dihargai oleh orang lain, di ukur dari pemberian insentif/bonus.

e. Kebutuhan untuk mengaktualisasi diri, yaitu kebutuhan untuk menggunakan kemampuan, skill dan potensi, diukur dari keterlibatan guru dalam pengambilan keputusan dan ide-ide kreatif.

2. Variabel Komunikasi $\left(\mathrm{X}_{2}\right)$ Komunikasi adalah proses penyampaian pesan dari sumber kepada suatu penerima melalui saluran untuk mencapai suatu hasil atau tujuan, yang di ukur 
dengan skala likert dengan indikator sebagai berikut :

- Tingkat kejelasan pemberian informasi

- Frekuensi penyampaian informasi

- Memiliki skill atau ketrampilan berkomunikasi

- Kelengkapan sarana komunikasi yang digunakan

3. Variabel Lingkungan Kerja $\left(\mathrm{X}_{3}\right)$

Lingkungan kerja adalah kondisi fisik dan non fisik tempat kerja dimana seorang karyawan melaksanakan tugas dan tanggung jawab sehari-hari yang di ukur berdasarkan skala Likert dengan indikator sebagai berikut :

a. Lingkungan kerja yang selalu bersih,sejuk, dan rindang

b. Tempat kerja yang memberikan rasa aman

c. Tersedianya alat-alat kerja yang memadai

d. Tersedianya ruang kerja yang mencukupi dan memadai serta lokasi yang jauh dari kebisingan

e. Tempat kerja yang mempunyai penerangan yang cukup.

4. Kinerja Karyawan (Y)

Kinerja karyawan adalah kemampuan yang dimiliki oleh seorang karyawan dalam melakukan tugas dan pekerjaannya sehingga terlihat prestasinya. yang di ukur berdasarkan skala likert dengan indikator sebagai berikut :

1) Karyawan dapat menyelesaikan jumlah hasil kerja sesuai dengan tuntutan yang diharapkan.

2) Karyawan menyelesaikan pekerjaannya sesuai standar kerja yang ditentukan.

3) Karyawan menunjukkan kesediaan melakukan pekerjaan tanpa perintah atau diminta atasan.

4) Karyawan mampu memberikan ide kreatif untuk kemajuan perusahaan

5) Karyawan bersedia melakukan pekerjaan yang bukan tugasnya dalam situasi mendesak demi kelancaran operasional.

6) Karyawan memiliki kedisiplinan (kehadiran, kesopanan, berpenampilan rapi, dan sebagainya).

7) Karyawan berusaha dengan sungguhsungguh menyelesaikan pekerjaan sampai tuntas.

8) Karyawan bersedia bekerja melewati batas waktu normal jika pekerjaannya belum selesai.

9) Karyawan memiliki kemampuan berkomunikasi dan bekerja sama, baik dengan sesama 
karyawan maupun dengan atasannya.

Untuk memperoleh data, peneliti menggunakan teknik pengumpulan data dengan cara :

1. Tinjauan kepustakaan

Penelitian yang dilakukan dengan cara mempelajari bukubuku yang berhubungan dengan masalah yang dihadapi dalam pembuatan tesis.

2. Penelitian lapangan

Yaitu melaksanakan pengamatan secara langsung di lapangan, pengumpulan data di lapangan diperoleh dengan cara

a. Wawancara (interview)

Yaitu melakukan teknik wawancara dengan bagian dan pihak yang terkait.

b. Pengamatan (observation) Yaitu dengan melakukan pengamatan secara langsung terhadap laporan-laporan yang diteliti

c. Kuesionair

Yaitu teknik pengumpulan data yang dilakukan melalui daftar pertanyaan yang dikirim melalui responden.

1. Skala Likert

Dalam

penelitian ini, teknik skala yang digunakan adalah skala Likert yang digunakan untuk mengukur sikap, pendapat dan persepsi seseorang atau sekelompok orang tentang fenomena sosial. Variabel yang diuku menjadi subvariabel, kemudian dijabarkan Berikut contoh tabel skala Likert di bawah ini :

Tabel 3.1
Tabel

Skala

Likert

\begin{tabular}{|l|l|}
\hline Pilihan Jawaban & Skor \\
\hline Sangat setuju & 5 \\
\hline Setuju & 4 \\
\hline Cukup setuju & 3 \\
\hline Kurang setuju & 2 \\
\hline Tidak setuju & 1 \\
\hline
\end{tabular}

Sumber : Sugiyono

(2009:107)

2. Skala Nominal

Skala nominal merupakan skala yang paling sederhana. Angka yang diberikan untuk satu kategori tidak menggambarkan kedudukan kategori tersebut terhadap kategori lainnya, tetapi angka tersebut hanya sekedar kode maupun label.

\section{UJI VALIDITAS}

$\begin{array}{rr}\text { Suatu } & \text { penelitian } \\ \text { dikatakan valid apabila }\end{array}$ terdapat kesamaan antara data yang terkumpul dengan sesungguhnya terjadi pada obyek yang diteliti (Sugiono, 2009 :109). Instrumen penelitian dikatakan valid jika $r$ hitung lebih besar dari $r$ tabel. Hal tersebut dapat menggunakan rumus korelasi (product moment) yaitu dengan mengkorelasikan variabel, dengan rumus sebagai berikut :

$$
\operatorname{rxy}=\frac{n \sum x y-\left(\sum x\right)(\Sigma y)}{\sqrt{\left(n \sum x^{2}-\left(\sum x^{2}\right)\right)\left(n \Sigma y^{2}-\left(\Sigma y^{2}\right)\right)}}
$$

Keterangan :

$\mathrm{r}_{\mathrm{xy}} \quad=$ koefisien korelasi

$\mathrm{N}=$ jumlah responden 
$\mathrm{y}=$ nilai/skor total kuesioner masing-masing responden

$\mathrm{x}=$ nilai/skor perbutir

Bila signifikan hasil korelasi

lebih dari $5 \%(0,05)$, maka dikatakan valid. Dalam melakukan analisis ini dibantu dengan menggunakan program SPSS

\section{UJI RELIABILITAS}

Dikemukakan oleh Nunnally (dalam Ghozali, 2002 :129) apabila penskoran butir lebih dari 2 (dua) kategori, maka besarnya reliabilitas dapat digunakan koefisien alpha. Berdasarkan pendapat di atas, maka untuk menguji reliabilitas masingmasing instrumen dalam penelitian ini dilakukan dengan menggunakan rumus Cronbach's Alpha. Rumus ini dapat ditulis sebagaiberikut :(Arikunto, 2002:174)

$\mathrm{r}=\left[\frac{k}{k-1}\right]\left[1-\frac{\sum \alpha_{b}^{2}}{\alpha^{2}}\right]$

$\mathrm{r}=$ reliabilitas instrumen

$\mathrm{k}=$ banyaknya butir pertanyaan atau banyaknya soal

$\cdot \Sigma_{\alpha^{2}}^{\alpha_{b}^{2}}=$ jumlah varians butir

,$\alpha^{2} \quad=$ varians total

Dalam pengujian ini dilakukan dengan cara one shot atau pengukuran sekali saja. Program SPSS memberikan fasilitas untuk reliabilitas dengan uji statistik Cronbach Alpha (a) > 0,60 (Nunally dalam Ghozali : 2002).

\section{UJI ASUMSI KLASIK}

a. Uji Normalitas Data

Uji normalitas bertujuan untuk menguji apakah dalam model regresi, variabel bebas dan variabel terikat mempunyai distribusi normal atau tidak. Pengujian yang digunakan untuk menguji kenormalan data yang diamati dalam penelitian ini adalah dengan menggunakan alat uji statistik kolmogorov-smirnov. Dari analisis statistik kolmogorov-smirnov dapat diperoleh nilai signifikansi masing-masing variabel di atas 5 $\%$ maka distribusi data adalah normal, sebaiknya jika kurang 5 $\%$ maka distribusi data tidak normal.

b. Uji autokorelasi

Akibat adanya autokorelasi menyebutkan uji-F dan uji-t tidak dapat diterapkan secara sah, karena jika tetap digunakan akan memberikan kesimpulan yang salah. Untuk mendeteksi adanya autokorelasi dengan melihat nilai Durbin Watson yang diperoleh dengan rumus :

$\mathrm{DW}=\frac{\sum_{t=T\left(e_{\left.t-e_{t-t}\right)}^{t=n}\right.}^{2}}{\sum e t^{2}}$

Dimana :

$\mathrm{e} \quad=$ nilai residual

$\mathrm{t}=$ jumlah responden

suatu persamaan regresi dikatakan telah memenuhi asumsi autokorelasi jika uji Durbin Watson lebih dari nilai batas bawah (dU) dan kurang dari 4-dU.

c. Uji multikolinearitas Multikolinearitas

menunjukkan adanya hubungan (korelasi) linier antara dua atau lebih variabel bebas dari model regresi. Dengan adanya multikolinearitas maka standar kesalahan masingmasing koefisien yang diduga akan sangat besar, sehingga pengaruh masing-masing variabel bebas tidak dapat dideteksi. Untuk melihat ada atau tidaknya gejala multikolinearitas dalam model regresi dapat dilakukan dengan cara melihat nilai Variance Inflator Faktor (VIF). Jika nilai $\mathrm{VIF}<10$ maka tidak terdapat gejala multikolinearitas dalam model 
regresi. Secara sitematis pengukuran multikolinearitas dapat merumuskan formula sebagai berikut : VIF $1 / 1$ (1-R2), dimana $\mathrm{R}^{2}=$ koefisien korelasi antar variabel bebas.

\section{METODE PENELITIAN}

1. Analisis Deskriptif

Analisis deskriptif prosentase belum mampu menjawab pertanyaan penelitian, karena hanya mengetahui jawaban responden atas skor ideal. Untuk itu perlu dilakukan analisa regresi.

2. Analisis Kuantitatif

\section{a. Model Regresi}

Model empirik yang digunakan untuk melakukan hipotesis dalam penelitian ini adalah :

$$
Y=\beta_{0}+\beta_{1} X_{1}+\beta_{2} X_{2}+\beta_{3} X_{3}
$$

$$
+\mathrm{e}
$$

Keterangan :

$$
\beta=\text { Konstanta }
$$

(intercept)

$$
\begin{array}{ll}
\mathrm{Y} & =\text { Kinerja Pegawai } \\
\mathrm{X}_{1}=\text { Motivasi } & \\
\mathrm{X}_{2}=\text { Komunikasi } \\
\mathrm{X}_{3}=\text { Lingkungan Kerja } \\
\beta_{1}, \beta_{2}, \beta_{3}, \beta_{4}=\text { Koefisien }
\end{array}
$$

Dalam penelitian ini hipotesis yang akan diuji adalah sebagai berikut :

a. Uji t

Untuk menguji signifikan atau tidaknya koefisien regresi secara parsial, dapat digunakan uji $\mathrm{t}$ dengan rumus :

$\mathrm{F}=\frac{r \sqrt{n-2}}{\sqrt{1-r^{2}}}$

Dimana :

$\mathrm{r}=$ nilai koefisien korelasi

$\mathrm{n}=$ jumlah populasi $\mathrm{r}^{2}=$ nilai koefisien determinasi atau kuadrat koefisien korelasi

b. Uji F

Untuk mengetahui ada tidaknya pengaruh variabel bebas secara keseluruhan terhadap variabel terikat, dapat digunakan pengujian $\mathrm{F}$ hitung sesuai dengan rumus :

Fo $=\frac{\frac{r^{2}}{k}}{\frac{1-r^{2}}{n}-k-1}$

Dimana :

$\mathrm{F}_{0} \quad: \mathrm{F}_{\text {hitung }}=\mathrm{F}_{\text {statistik }}$

$\mathrm{R}^{2}$ : $\quad$ Koefisien

determinan

n : Jumlah sample

$\mathrm{k}$ : Jumlah variabel bebas

$1-\mathrm{R}^{2}$ : Regional Sum Squares

c. $\mathrm{Uji} \quad \mathrm{R}^{2} \quad$ (koefisien determinasi)

Untuk dapat mengetahui presentasi konstribusi atau pengaruh semua variabel bebas (X) diantara variabel-variabel lainnya terhadap variabel terikat $(\mathrm{Y})$, maka uji $\mathrm{R}^{2}$ (koefisien determinasi). Seluruh penghitung pengujian di atas menggunakan bantuan komputer program SPSS forwindows versi 20.

\section{HASIL ANALISIS \&}

PEMBAHASAN

Hasil analisis

Uji validitas instrumen penelitian

Hasil pengukuran

validitas instrumen penelitian diperoleh hasil $\mathrm{r}$ hitung (Pearson Correlation) seperti yang tersaji dalam tabel berikut ini :

Tabel 4.1

Nilai Uji Validitas Instrumen Penelitian 


\begin{tabular}{|c|c|c|c|c|}
\hline No. & Indikator & \begin{tabular}{|l|} 
Koefisien \\
Korelasi
\end{tabular} & r tabel & Keterangan \\
\hline 1 & $\mathrm{X} 1.1$ & 0,803 & 0,1290 & Valid \\
\hline 2 & $\mathrm{X} 1.2$ & 0,844 & 0,1290 & Valid \\
\hline 3 & X1.3 & 0,853 & 0,1290 & Valid \\
\hline 4 & X1.4 & 0,860 & 0,1290 & Valid \\
\hline 5 & X1.5 & 0,868 & 0,1290 & Valid \\
\hline 6 & X1.6 & 0,872 & 0,1290 & Valid \\
\hline 7 & X1.7 & 0,863 & 0,1290 & Valid \\
\hline 8 & $\mathrm{X} 1.8$ & 0,875 & 0,1290 & Valid \\
\hline 9 & X1.9 & 0,876 & 0,1290 & Valid \\
\hline 10 & $\mathrm{X} 10$ & 0,777 & 0,1290 & Valid \\
\hline 11 & $\mathrm{X} 11$ & 0,881 & 0,1290 & Valid \\
\hline 12 & $\mathrm{X} 12$ & 1 & 0,1290 & Valid \\
\hline 13 & $\mathrm{X} 2.1$ & 0,549 & 0,1290 & Valid \\
\hline 14 & $\mathrm{X} 2.2$ & 0,472 & 0,1290 & Valid \\
\hline 15 & $\mathrm{X} 2.3$ & 0,462 & 0,1290 & Valid \\
\hline 16 & $\mathrm{X} 2.4$ & 0,341 & 0,1290 & Valid \\
\hline 17 & X3.1 & 0,572 & 0,1290 & Valid \\
\hline 18 & X3.2 & 0,676 & 0,1290 & Valid \\
\hline 19 & X3.3 & 0,635 & 0,1290 & Valid \\
\hline 20 & X3.4 & 0,579 & 0,1290 & Valid \\
\hline 21 & $\mathrm{X} 3.5$ & 0,630 & 0,1290 & Valid \\
\hline 22 & Y1.1 & 0,560 & 0,1290 & Valid \\
\hline 23 & Y1.2 & 0,478 & 0,1290 & Valid \\
\hline 24 & Y1.3 & 0,555 & 0,1290 & Valid \\
\hline 25 & \begin{tabular}{|l|}
$Y 1.4$ \\
\end{tabular} & 0,575 & 0,1290 & Valid \\
\hline 26 & Y1.5 & 0,600 & 0,1290 & Valid \\
\hline 27 & Y1.6 & 0,601 & 0,1290 & Valid \\
\hline 28 & Y1.7 & 0,615 & 0,1290 & Valid \\
\hline 29 & Y1.8 & 0,625 & 0,1290 & Valid \\
\hline 30 & Y1.9 & 0,537 & 0,1290 & Valid \\
\hline $\begin{array}{l}\text { Sumber : lampiran } 3 \text { (diolah } \\
\text { Januari 2016) }\end{array}$ & $\begin{array}{l}\text { : lampira } \\
\text { 2016) } \\
\text { Berdasar } \\
\text { menunjukl }\end{array}$ & $\begin{array}{lr}3 & \text { (diolah } \\
\text { bel } & 4.1 . \\
n & \text { bahwa }\end{array}$ & $\begin{array}{l}\text { dengan } \\
\text { instrumen } \\
\text { digunakan } \\
\text { variabel do }\end{array}$ & $\begin{array}{l}\text { demikian bahwa } \\
\text { penelitian yang } \\
\text { untuk mengukur } \\
\text { pat dikatakan valid. }\end{array}$ \\
\hline
\end{tabular}

nilai $r$ hitung (koefisien

korelasi) lebih besar dari 0,3, 
UJI RELIABILITAS INSTRUMEN PENELITIAN

Pengukuran uji

reliabilitas diperoleh hasil sebagai berikut :

\section{Tabel 4.2}

Nilai Uji Reliabilitas

Instrumen Penelitian

\begin{tabular}{|l|l|l|}
\hline $\begin{array}{l}\text { n } \\
\mathbf{o}\end{array}$ & $\begin{array}{l}\text { Variabel } \\
\text { Penelitia } \\
\mathbf{n}\end{array}$ & $\begin{array}{l}\text { Nilai } \\
\text { Alpha } \\
\text { Cronbac } \\
\text { h }\end{array}$ \\
\hline 1 & $\begin{array}{l}\text { Motivasi } \\
\text { (X1) }\end{array}$ & 0,937 \\
\hline 2 & $\begin{array}{l}\text { Komunik } \\
\text { asi (X2) }\end{array}$ & 0,651 \\
\hline 3 & $\begin{array}{l}\text { Lingkung } \\
\text { an Kerja } \\
\text { (X3) }\end{array}$ & 0,661 \\
\hline 4 & $\begin{array}{l}\text { Kinerja } \\
\text { (Y) }\end{array}$ & 0,948 \\
\hline
\end{tabular}

Sumber : lampiran 4 (diolah Januari 2016)

Berdasar tabel diatas

nilai Alpha Cronbach dari masing-masing variabel lebih dari 0,6 sehingga dapat

UJI NORMALITAS DENGAN KOLMOGOROV-SMIRNOV ONE-SAMPLE KOLMOGOROV -SMIRNOV TEST

\begin{tabular}{|l|l|l|}
\hline & & $\begin{array}{l}\text { Unstandardized } \\
\text { Residual }\end{array}$ \\
\hline $\mathrm{N}$ & & 40 \\
\hline Normal Parameters ${ }^{\mathrm{a}, \mathrm{b}}$ & Mean &, 0000000 \\
\hline & Std. Deviation & .40250773 \\
\hline Most Extreme & Absolute &, 088 \\
\hline Differences & Positive &, 088 \\
\hline & Negative &, 067 \\
\hline Kolmogorov-Sminov Z & &, 596 \\
\hline Asymp. Sig. (2-tailed) & &, 867 \\
\hline
\end{tabular}

dikatakan bahwa semua itemitem dalam kuesioner penelitian tersebut adalah reliable.

Uji asumsi klasik

\section{a) Uji Normalitas}

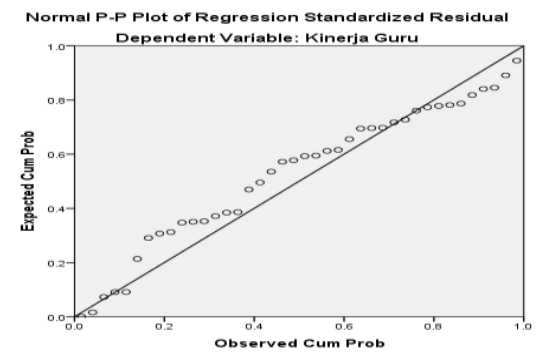

pada grafik telah mendekati atau hampir berhimpit dengan sumbu diagonal atau membentuk sudut 45 derajad dengan garis mendatar. Interpretasinya adalah bahwa nilai residual pada model penelitian telah terdistribusi secara normal. Untuk memperkuat hasil pengujian tersebut dipergunakan uji kolmogorovSmirnov yaitu sebagai berikut :

Tampak bahwa nilai signifikansi adalah sebesar $0,867>0,05$ yang menunjukkan bahwa nilai residual telah terdistribusi secara normal. 
UJI AUTOKORELASI

Berikut adalah nilai Durbin-Watson pada model penelitian ini :

\begin{tabular}{|c|c|c|c|c|c|}
\hline $\begin{array}{l}\text { Mode } \\
1\end{array}$ & $\mathrm{R}$ & $\begin{array}{l}\mathrm{R} \\
\text { Square }\end{array}$ & $\begin{array}{l}\text { Adju } \\
\text { sted } \\
\text { R } \\
\text { Squar } \\
\text { e }\end{array}$ & $\begin{array}{l}\text { Std. } \\
\text { Error } \\
\text { of the } \\
\text { Estim } \\
\text { ate }\end{array}$ & $\begin{array}{l}\text { Durbi } \\
\text { n- } \\
\text { Wats } \\
\text { on }\end{array}$ \\
\hline 1 & $\begin{array}{l}, 726 \\
\text { a }\end{array}$ & ,527 & ,496 & $\begin{array}{l}, 3093 \\
3\end{array}$ & 1,728 \\
\hline
\end{tabular}

Adapun nilai dU untuk 3 buah variabel dengan 40 data pada taraf 5\% adalah sebesar 1,728. Tampak bahwa $0<\mathrm{dW}<\mathrm{Du}$ yang masuk pada kategori no decision. Untuk memperkuat hasil tersebut digunakan uji Run, dimana gangguan autokorelasi terjadi signifikansi dibawah 0,05. Berikut adalah uji autokorelasi dengan Run test :

Uji Autokorelasi dengan Run Test

\begin{tabular}{|l|l|}
\hline & $\begin{array}{l}\text { Unstandard } \\
\text { ized } \\
\text { Residual }\end{array}$ \\
\hline Test Value $^{\mathrm{a}}$ &, 04540 \\
\hline $\begin{array}{l}\text { Cases }<\text { Test } \\
\text { Value }\end{array}$ & 26 \\
\hline $\begin{array}{l}\text { Cases > }= \\
\text { Test Value }\end{array}$ & 14 \\
\hline Total Cases & 40 \\
\hline $\begin{array}{l}\text { Number of } \\
\text { Runs }\end{array}$ & 26 \\
\hline Z &, 310 \\
\hline $\begin{array}{l}\text { Asymp. Sig. } \\
\text { (2-tailed) }\end{array}$ &, 760 \\
\hline
\end{tabular}

a. Median

Tampak bahwa signifikansi adalah sebesar $0,760>0,05$ yang menunjukkan bahwa tidak terjadi gangguan autokorelasi pada model penelitian ini.

\section{UJI MULTIKOLINIERITAS}

Uji multikolinearitas dilakukan dengan meng unakan nilai variance inflation factor (VIF). Model dinyatakan terbebas dari gangguan multikolinearitas jika mempunyai nilai VIF dibawah 10 atau tolerance diatas 0,1 .

\section{Coefficients $^{\mathrm{a}}$}

\begin{tabular}{|c|c|c|c|c|c|c|c|}
\hline \multirow[b]{2}{*}{ Model } & \multicolumn{2}{|c|}{$\begin{array}{l}\text { Unst } \\
\text { andar } \\
\text { dized } \\
\text { Coef } \\
\text { ficie } \\
\text { nts }\end{array}$} & $\begin{array}{l}\text { Sta } \\
\text { nda } \\
\text { rdi } \\
\text { zed } \\
\text { Co } \\
\text { effi } \\
\text { cie } \\
\text { nts }\end{array}$ & & & \multicolumn{2}{|c|}{$\begin{array}{l}\text { Colline } \\
\text { arity } \\
\text { Statisti } \\
\text { cs }\end{array}$} \\
\hline & B & $\begin{array}{l}\text { S } \\
\text { t } \\
\text { d. } \\
\text { E } \\
\text { rr } \\
\text { o } \\
\text { r }\end{array}$ & $\begin{array}{l}\text { Bet } \\
a\end{array}$ & $\mathrm{t}$ & $\begin{array}{l}\mathrm{Si} \\
\mathrm{g} .\end{array}$ & $\begin{array}{l}\mathrm{T} \\
\text { ol } \\
\text { er } \\
\text { an } \\
\text { ce }\end{array}$ & $\begin{array}{l}\text { VI } \\
\text { F }\end{array}$ \\
\hline $\begin{array}{l}1 \text { (Const } \\
\text { ant) }\end{array}$ & $\begin{array}{l}2 \\
6 \\
6 \\
7 \\
2\end{array}$ & $\begin{array}{l}, 4 \\
7 \\
0\end{array}$ & & $\begin{array}{l}1, \\
42 \\
9\end{array}$ & $\begin{array}{l}, 0 \\
00\end{array}$ & & \\
\hline $\begin{array}{l}\text { Motiva } \\
\text { si }\end{array}$ & & $\begin{array}{l}, 0 \\
9\end{array}$ & $\begin{array}{l}, 56 \\
5\end{array}$ & $\begin{array}{l}5, \\
48\end{array}$ & $\begin{array}{l}, 0 \\
00\end{array}$ & $\begin{array}{l}, 9 \\
70\end{array}$ & $\begin{array}{l}1, \\
03\end{array}$ \\
\hline & $\begin{array}{l}9 \\
4\end{array}$ & 0 & & 4 & & & 1 \\
\hline Komu & , & ,0 & ,37 & 3 & ,0 &, 9 & 1 \\
\hline nikasi & $\begin{array}{l}3 \\
1 \\
4\end{array}$ & $\begin{array}{l}8 \\
8\end{array}$ & 8 & $\begin{array}{l}58 \\
4\end{array}$ & 01 & 25 & $\begin{array}{l}08 \\
1\end{array}$ \\
\hline $\begin{array}{l}\text { Lingku } \\
\text { ngan }\end{array}$ & 5 & $\begin{array}{l}, 1 \\
0\end{array}$ & $\begin{array}{l}, 60 \\
1\end{array}$ & $\begin{array}{l}5, \\
51\end{array}$ & $\begin{array}{l}, 0 \\
00\end{array}$ & $\begin{array}{l}, 9 \\
53\end{array}$ & $\begin{array}{l}1, \\
05\end{array}$ \\
\hline kerja & $\begin{array}{l}0 \\
1\end{array}$ & 1 & & 0 & & & 0 \\
\hline
\end{tabular}

a. Dependent Variable: Kinerja karyawan Berikut adalah uji Multikolinearitas dalam penelitian ini : 
Berdasarkan hasil perhitungan diatas dapat dilihat bahwa nilai tolerance dari seluruh variabel dependen lebih besar dari 0.10. Dan nilai VIF semua variabel bebas lebih kecil dari 10, sehingga tidak terjadi gejala korelasi antar variabel bebas terhadap kinerja guru.

\section{Analisis regresi linier berganda}

Analisis regresi linier berganda bertujuan untuk mengetahui hubungan antara dua variabel, yaitu antara variabel bebas dengan variabel terikat dalam suatu penelitian. Proses perhitungan ini dilakukan dengan menggunakan bantuan software statistik SPSS (Statistical Program for Social Sciences) 20 for windows version.

Berdasar analisis data, maka diperoleh suatu hasil seperti tersaji dalam tabel berikut ini :

Tabel 4.3

\section{Koefisien Regresi Linier Berganda}

\begin{tabular}{|c|c|c|c|c|}
\hline $\begin{array}{l}\text { Variabel } \\
\text { Bebas }\end{array}$ & $\begin{array}{l}\text { Koef } \\
\text { isien }\end{array}$ & $\begin{array}{l}\text { Bet } \\
\mathrm{a}\end{array}$ & $\begin{array}{l}\mathrm{T}_{\text {hit }} \\
\text { ung }\end{array}$ & Sig \\
\hline $\begin{array}{l}\text { Konstant } \\
\text { a }\end{array}$ & $\begin{array}{l}2,67 \\
2\end{array}$ & - & $\begin{array}{l}1,4 \\
29\end{array}$ & $\begin{array}{l}0,0 \\
00\end{array}$ \\
\hline $\begin{array}{l}\text { Motivasi } \\
\text { (X1) }\end{array}$ & $\begin{array}{l}0,49 \\
4\end{array}$ & $\begin{array}{l}0,56 \\
5\end{array}$ & $\begin{array}{l}5,4 \\
84 \\
\end{array}$ & $\begin{array}{l}0,0 \\
00\end{array}$ \\
\hline $\begin{array}{l}\text { Komuni } \\
\text { kasi } \\
(\mathrm{X} 2)\end{array}$ & $\begin{array}{l}0,31 \\
4\end{array}$ & $\begin{array}{l}0,37 \\
8\end{array}$ & $\begin{array}{l}3,5 \\
84\end{array}$ & $\begin{array}{l}0,0 \\
01\end{array}$ \\
\hline $\begin{array}{l}\text { Lingkun } \\
\text { gan } \\
\text { Kerja } \\
\text { (X3) }\end{array}$ & $\begin{array}{l}0,50 \\
1\end{array}$ & $\begin{array}{l}0,60 \\
1\end{array}$ & $\begin{array}{l}5,5 \\
10\end{array}$ & $\begin{array}{l}0,0 \\
00\end{array}$ \\
\hline \multicolumn{2}{|c|}{$\begin{array}{l}\text { Koefisien } \\
\text { Korelasi (R) }\end{array}$} & \multicolumn{3}{|c|}{$: 0,726$} \\
\hline \multicolumn{2}{|c|}{ Koefisien } & \multicolumn{3}{|c|}{$: 0,527$} \\
\hline
\end{tabular}

\begin{tabular}{|lc|l|}
\hline $\begin{array}{l}\text { Determinasi } \\
\text { Square) }\end{array}$ & $(\mathrm{R}$ & \\
\hline $\begin{array}{l}\text { Adjusted } \\
\text { square }\end{array}$ & $\mathrm{R}$ & $: 0,496$ \\
\hline $\mathrm{F}_{\text {hitung }}$ & $: 17,100$ \\
\hline Signifikansi F & $: 0,000$ \\
\hline
\end{tabular}

Sesuai dengan model analisis yang digunakan, yaitu regresi linier berganda, maka dapat dilakukan analisis dengan rumus umum sebagai berikut :

$\mathrm{Y}=\beta_{0}+\beta_{1} \mathrm{X}_{1}+\beta_{2} \mathrm{X}_{2}+\beta_{3} \mathrm{X}_{3}+\mathrm{e}$ $\mathrm{Y}=2,672+0,494 \mathrm{X}_{1}+0,314 \mathrm{X}_{2}+$ $0,501 \mathrm{X}_{3}+\mathrm{e}$

Nilai-nilai koefisien regresi linier berganda dari persamaan diatas dapat dijelaskan sebagai berikut :

1. $\beta_{0}$ (konstanta) $=2,672$, besarnya nilai tersebut memberikan asumsi bahwa jika nilai dari variabel Motivasi (X1), Komunikasi (X2), Lingkungan kerja (X3) adalah sebesar 0, maka besarnya nilai Kinerja karyawan (Y) di PT Andalan Pasific Samudra adalah sebesar 2,672.

2. $\beta_{1}=0,494$, hal tersebut menunjukkan bahwa setiap peningkatan nilai variabel Motivasi (X1) sebesar satu satuan dengan anggapan variabel-variabel yang lain dalam kondisi tetap, akan mengakibatkan perubahan dengan arah yang sama terhadap nilai Motivasi (X1) sebesar 0,494 atau untuk setiap peningkatan nilai Motivasi (X1) sebesar satu satuan, maka nilai Kinerja karyawan (Y) di PT Andalan Pasific Samudra juga akan mengalami kenaikan sebesar 0,494.

3. $\beta_{2}=0,314$, hal tersebut menunjukkan bahwa setiap peningkatan nilai variabel Komunikasi (X2) sebesar satu 
satuan dengan anggapan variabel-variabel yang lain dalam kondisi tetap, akan mengakibatkan perubahan dengan arah yang sama terhadap nilai Komunikasi (X2) sebesar 0,314 atau untuk setiap peningkatan nilai Komunikasi (X2) sebesar satu satuan, maka nilai Kinerja karyawan(Y) di PT Andalan Pasific Samudra juga akan mengalami kenaikan sebesar 0,314.

4. $\beta_{3}=0,501$, hal tersebut menunjukkan bahwa setiap peningkatan nilai variabel Lingkungan kerja (X3) sebesar satu satuan dengan anggapan variabel-variabel yang lain dalam kondisi tetap, akan mengakibatkan perubahan dengan arah yang sama terhadap nilai Lingkungan kerja (X3) sebesar 0,501 atau untuk setiap peningkatan nilai Lingkungan kerja (X3) sebesar satu satuan, maka nilai Kinerja karyawan(Y) di PT Andalan Pasific Samudra juga akan mengalami kenaikan sebesar 0,501 .

Nilai Koefisien Determinasi $(R$ square) variabel penelitian

Untuk mengetahui seberapa

besar kontribusi dari variabel Motivasi (X1), Komunikas (X2), Lingkungan kerja (X3) terhadap Kinerja karyawan (Y) di PT Andalan Pasific Samudra diketahui pada nilai R Square yakni sebesar 0,527 (lihat tabel 4.7). ini mengandung arti bahwa Motivasi (X1), Komunikasi (X2), Lingkungan Kerja (X3) terhadap variabel terikat yaitu Kinerja (Y) di PT Andalan Pasific Samudra adalah sebesar 0,527 atau 52,7\%. Sedangkan sisanya sebesar $47,3 \%$ dijelaskan oleh variabel lain yang tidak masuk dalam model penelitian ini. Hal tersebut menunjukkan bahwa variabel Motivasi (X1) , variabel Komunikasi (X2), Lingkungan kerja (X3) mampu memberikan kontribusi yang signifikan terhadap Kinerja karyawan, (Y) di PT Andalan Pasific Samudra.

\section{Pengujian Hipotesis}

Hipotesis pertama dan Hipotesis kedua yang menyatakan bahwa terdapat pengaruh yang signifikan baik secara simultan (dengan uji F) maupun secara parsial (dengan uji t) antara variabel Motivasi (X1), Komunikasi (X2), Lingkungan kerja (X3) terhadap Kinerja (Y) di PT Andalan Pasific Samudra dibuktikan dengan menggunakan analisis regresi linier berganda. Berikut hasil dan uraian dari pengujian hipotesis pertama dan hipotesis kedua.

1. Pengujian Hipotesis Pertama (secara parsial atau Uji t)

Uji t (uji parsial) ini adalah untuk mengetahui berpengaruh (signifikan) atau tidak dari masing-masing variabel Motivasi Kerja (X1), Komunikasi (X2), Lingkungan Kerja (X3) terhadap Kinerja (Y) di PT Andalan Pasific Samudra. Pengujian hipotesis secara parsial dengan cara melihat nilai signifikansi yang didapat untuk masing-masing variabel. Jika nilai signifikansi dari nilai $\mathrm{t}$ hitung masing-masing variabel lebih kecil dari nilai $(\alpha)$ sebesar $(0,05)$, maka hipotesis diterima berarti, variabel bebas secara parsial berpengaruh signifikan terhadap variabel terikat. Akan tetapi, apabila nilai signifikansi dari masing-masing variabel 
bebas lebih besar dari nilai $(\alpha)$ sebesar $(0,05)$, maka hipotesis ditolak yang berarti variabel bebas tidak berpengaruh secara parsial terhadap variabel terikat. Hasil pengujian hipotesis kedua (H1) yang didapat adalah :

Hasil pengujian secara parsial untuk variabel Motivasi (X1), komunikasi (X2), dan Lingkungan Kerja (X3) diperoleh nilai signifikansi adalah sebesar 0,000 yang mana nilai tersebut lebih kecil dari nilai $(\alpha)$ sebesar $(0,05)$ sehingga H1 yang menyatakan bahwa secara parsial variabel Motivasi (X1), Komunikasi (X2), dan lingkungan kerja (X3) berpengaruh terhadap Kinerja karyawan (Y) di PT Andalan Pasific Samudra.

\section{Pengujian Hipotesis Kedua F)}

Uji F dimaksudkan untuk membuktikan pengaruh variabel Motivasi (X1), Komunikasi guru (X2), Lingkungan Kerja (X3) secara simultan terhadap Kinerja karyawan (Y) di PT Andalan Pasific Samudra. Langkahlangkah pengujian tersebut adalah dengan berdasarkan pada nilai signifikansi. Jika nilai signifikansi yang didapat lebih kecil dari nilai alpha $(\alpha)$ sebesar 0,05 maka hipotesis diterima yang berarti secara bersamasama bahwa variabel bebas berpengaruh signifikan terhadap variabel terikat. Akan tetapi apabila nilai signifikan pada $\mathrm{F}$ hitung lebih besar dari nilai alpha $(\alpha)$ sebesar 0,05 , maka hipotesis ditolak yang berarti secara simultan variabel bebas tidak berpengaruh signifikan terhadap variabel terikat.
Hasil analisis regresi linier diperoleh $\mathrm{F}$ hitung sebesar 16,499 dengan nilai signifikansi sebesar 0,000 . Nilai signifikansi tersebut lebih kecil dari nilai alpha $(\alpha)$ sebesar $0,05(0,000<$ 0,05). Dengan demikian hipotesis pertama (H1) yang menyatakan bahwa secara simultan Motivasi(X1), Komunikasi (X2), Lingkungan kerja (X3) berpengaruh signifikan terhadap Kinerja (Y) di PT Andalan Pasific Samudra.

\section{PENUTUP}

Berdasarkan hasil analisis penelitian dapat disimpulkan sebagai berikut :

1. Berdasarkan hasil pengujian hipotesis pertama menunjukkan bahwa secara parsial variabel bebas Motivasi (X1), Komunikasi (X2), dan Lingkungan kerja (X3) berpengaruh positif terhadap Kinerja Karyawan (Y) di PT Andalan Pasific Samudra.

2. Berdasarkan hasil pengujian hipotesis kedua (secara bersamasama) menunjukkan bahwa secara simultan variabel Motivasic(X1), Komunikasi (X2), dan Lingkungan Kerja (X3) berpengaruh signifikan terhadap Kinerja Guru (Y) di PT Andalan Pasific Samudra.

3. Hasil analisa koefisien determinasi R-Squared yakni sebesar 0,527, ini menunjukkan bahwa Motivasi (X1), Komunikasic(X2), Lingkungan Kerja (X3) terhadap variabel terikat yaitu Kinerja Guru (Y) di PT Andalan Pasific Samudra adalah sebesar 0,527 atau $52,7 \%$. 
Sehingga dapat diinterpretasikan bahwa variabel Motivasi (X1), Komunikasi (X2), Lingkungan Kerja (X3) mampu memberikan kontribusi yang signifikan terhadap Kinerja karyawan di PT Andalan Pasific Samudra.

\section{SARAN}

Dalam meningkatkan komunikasi antarpribadi karyawan, perlu ada pelatihan cara berkomunikasi yang efektif. Karena berkomunikasi merupakan suatu keterampilan yang dipelajari.

Pemberdayaan karyawan yang kinerjanya rendah perlu dilakukan secara teratur sehingga dapat meningkatkan kinerja yang diinginkan/standarkerja.

\section{DAFTAR PUSTAKA}

Arikunto, Suharsimi. 2002. Prosedur Penelitian, Suatu Pendekatan Praktek. Jakarta : : Rhinekka Cipta.

Ghozali. 2002. Aplikasi Analisis Multivariate dengan Program SPSS. Semarang : Penerbit Universitas Diponegoro.

Hasibuan, Malayu. 2005. Organisasi dan Motivasi. Jakarta : PT. Bumi Aksara.

Istijanto. 2008. Perilaku Organisasi. Jakarta : PT. Prenhalindo

Mangkunegara, Prabu. 2001. Manajemen Sumber Daya Manusia. Bandung : PT. Remaja Rosda Karya

Mangkunegara, Prabu. 2009. Evaluasi Kinerja SDM.

Bandung : PT. Refika Aditama

Nitisemito. 2003. Peranan Komunikasi Dalam Organisasi. Surakarta : PT. Bumi Ketingan
Sarwono. 2008. pengaruh signifikan secara parsial kemampuan, motivasi, dan lingkungan kerja terhadap kinerja guru. Jurnal Ekonomi. (Online), (http/www.google.com, diakses 15 Desember 2015)

Sugiyono. 2009. Statistika untuk

Penelitian dan Aplikasinya Berdasarkan desk Dengan SPSS. Bandung :

Alfabeta

Utami. 2010. pengaruh kepemimpinan, motivasi, komunikasi, dan lingkungan kerja terhadap kinerja pegawai kecamatan Jumantono Kabupaten Karanganyar.Jurnal

Ekonomi. (Online), (http/www.google.com, diakses 15 Desember 2015)

Widiyanti. 2002. Manajer Dan Bawahan, Jakarta:PT. Pustaka Binaman Pressindo

Winardi, J. 2002. Motivasi dan Pemotivasian Dalam Manajemen. Jakarta : PT. Remaja Rosda Karya

Wursanto. 2000. Komunikasi Organisasi. Bumi Aksara, Jakarta

Zainun. 2000. Manajemen Sumber Daya Manusia. Jakarta : Bumi Aksara 